\title{
HYBRID SUBURBIA: NEW RESEARCH PERSPECTIVES IN FRANCE AND SOUTHERN CALIFORNIA
}

\author{
Florian Weber, Olaf KüHNE \\ Department of Geography, University of Tübingen, Germany \\ Manuscript received: April 18, 2017 \\ Revised version: August 4, 2017
}

\begin{abstract}
WEBER F., KÜHNE O., 2017. Hybrid suburbia: New research perspectives in France and Southern California. Quaestiones Geographicae 36(4), Bogucki Wydawnictwo Naukowe, Poznań, pp. 17-28, 8 figs.

AвSTRACT: Geographical research on French and US suburbia has concentrated in recent decades on urban sprawl and concomitant processes of devaluation and exclusion. In the case of the French banlieues, with their much-publicised urban riots, this particular analytic focus has become overwhelming, with resultant loss to other developments and perspectives. However, certain districts in the first (or inner) ring of both French and US suburbia are currently showing distinct urbanisation tendencies in planning and architecture, evident in the new usage of brownfield sites and the ongoing demolition, replacement, and rededication of the older building core. Such processes induce population changes, e.g. the displacement of lower in favour of higher income groups. Overall, they result in an architectonic, social and cultural heterogeneity that escapes the specificity of received categories and merits the term hybridisation. The article describes and compares these processes as exemplified in Greater Paris and San Diego (Southern California).
\end{abstract}

KeYwords: suburbia, Southern California, France, stigmatisation, urban-rural hybrids

Corresponding author: Florian Weber, University of Tübingen, Department of Geography, Rümelinstr. 19-23, D-72070

Tübingen, Germany; e-mail: florian.weber@uni-tuebingen.de

\section{Introduction}

Suburbia - a space where a family finds 'its own safe haven', or a domain of fear, insecurity and faceless high-rise estates? A green-belt idyll, or an endless nightmare of traffic and industrial confusion? An oasis of peace and contemplation, or a cauldron of contradictions? A desirable residential area, or a launch-pad to hopelessness? Dichotomies of this sort could be taken a good deal further, but in all of them - it is increasingly clear - the connector 'or' can and should be replaced with 'and'. In the age of globalisation, hybridisation and postmodernism, an attempt to maintain the traditional contrastive stereotypes of city, suburbia and country is doomed to failure (Dear, Flusty 1998; Ellin 1999; Kühne 2012).
The concept of urban-rural hybrid (Kühne 2012; Kühne et al. 2016), although itself constituted by contradictions, oppositions, and ambiguities (Kühne, Schönwald 2015; Weber 2017), has proven a useful tool with which to approach differences between the city and the country without imputing any such dichotomy. This is so because the differentiation it proposes is "based on structural (levels of building), functional (levels of centrality), and lifestyle (urban/suburban/rural mix), as well as emotional (sense of belonging) and cognitive (especially in settlement research) considerations" (Kühne et al. 2016: 25). In the face of an oversimplified distinction between an urban core and the surrounding countryside, it addresses the interpenetration of the urban, suburban and rural beyond the city centre - in other 
words in the necklace of settlements traditionally thought of as 'suburbia'.

Geographical research has tended to isolate phenomena like segregation and gentrification, viewing them singly - albeit also in their interactions - but overlooking the spatial contiguities and overlaps of what amounts to a complex mosaic. The dominant focus, whether on the gentrification of the inner city or on the exclusion and downward mobility in the suburbs, tends to bypass a third, equally important movement observable in former suburban residential areas - a phenomenon to which we have sought to draw attention with the acronym URFSURBS: the 'urbanisation of former suburbs' (Kühne et al. 2016, 2017). Thus, in the two regions studied here, Greater Paris and Southern California, suburban buildings tend to be lower and more compartmentalised than those of inner cities and CBDs, and population densities are also lower (Kling et al. 1995; McManus, Ethington 2007; Teaford 2011). At the same time greater homogeneity can be observed in population structures, most clearly, perhaps, in the predominance of single-family housing over large residential complexes (Kirszbaum 2015; Soulignac 1993; Vieillard-Baron 2011).

However, recent years have seen changes that defy unidimensional categorisation: in particular the urban-rural dichotomy is proving increasingly untenable (Stébé, Marchal 2007: 57), its boundaries blurring in favour of the urban-rural hybrids mentioned above. At the same time, some formerly rural areas are being transformed into more traditional suburbia. Accordingly, the new URFSURBS are embedded in a 'spatial and functional pastiche' (Kühne 2012), in which formerly clear functional distinctions have been successively supplanted with mixed structures ranging from new use, through reuse, and reduction in use, to disuse (Kühne 2016). The creation of such pastiches does not imply "the erosion of differentiation: it presupposes differentiation and develops it in the direction of hybrid crossings, recombinations, and reintegration" (Vester 1993: 29, original emphasis; Hoesterey 2001).

Urbanisation tendencies are evident at both city planning and architectonic levels, in the new usage of brownfield sites and the ongoing demolition, replacement, and rededication of the older building substance. And these processes induce population changes, including the displacement of lower in favour of higher income groups. In all, they result in an architectonic, social and cultural heterogeneity that escapes the specificity of received categories and merits the term 'hybridisation' (Bourdieu 1989).

Against this background, the present article follows a shift in research perspectives toward the description and elucidation of hybrid forms of spatial development based on statistical evidence, interviews, and field research in the regions cited above. Aimed at a current gap in geographical research, the article presents a comparative analysis of locations in France and Southern California which reveal striking parallels, above all with respect to closely interconnected tendencies of urbanisation, gentrification and hybridisation in the banlieues and 'inner ring suburbs'.

\section{France. The banlieues - problem areas or development poles?}

Associated above all with the large cities of Paris, Lyon, Marseilles, St. Etienne, and Lille, the French banlieues - urban areas outside the inner city - suffer from an almost overwhelming weight of research, and a predominant focus on exclusion, architectonic decay, and infrastructural dereliction, segregation and stigmatisation.

In the Middle Ages banlieue was originally a legal term. Composed of two elements, the Germanic root-word Bann (jurisdiction) and the Latin leuga (league - which in French became lieue) designated an area that could be crossed in about one hour: this was the limit of mayoral power (Paulet 2004; Thinard 2008; VieillardBaron 1996). The rapid growth of cities in the wake of 19th century industrialisation led to a shift in meaning, and the word was increasingly applied to peripheral, but still essentially urban districts (Vieillard-Baron 2008, 2011). In the 20th century this usage continued, but as cities expanded into agglomerations, banlieue became the word for the marginal remainder that was neither properly a city nor anything else (Boyer 2000: 14-16; Weber et al. 2012: 50). This was especially the case in and after the 1960s and 70s, when the acute post-war housing shortage led to the construction of residential estates on and 


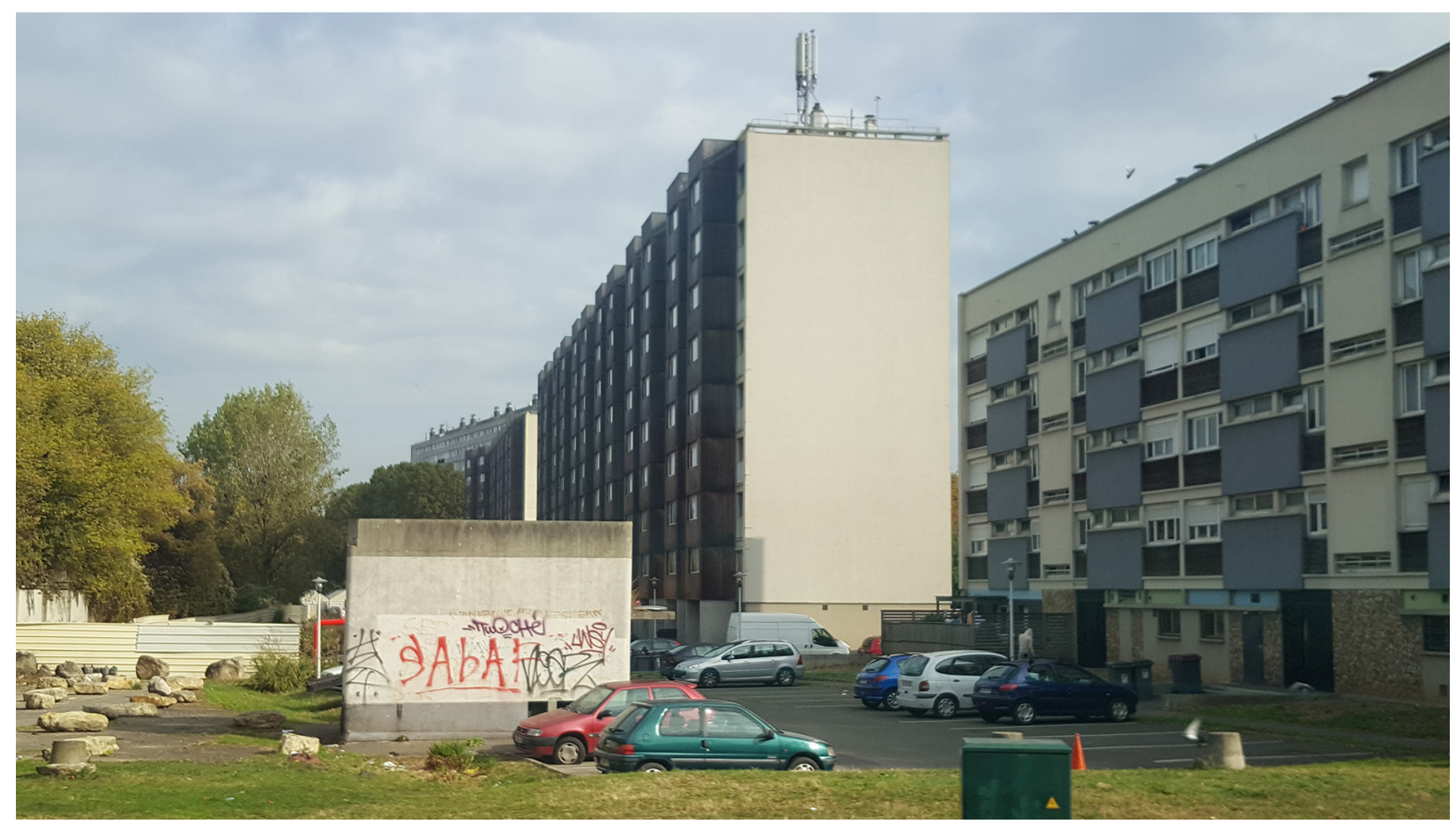

Fig. 1. High rise blocks in Bondy-Nord (eastern rim of Paris). Photo by Florian Weber (2016).

beyond suburban limits. The utopian vision of infrastructure with poor public transport, and creating a unified society (Donzelot 2004: 16) the inevitably resultant introversion. To this was quickly collapsed in the face of low-quality fac- added the stigmatisation associated with the tory-made buildings (Figs 1 and 2), a defective influx into empty accommodation - or forcible

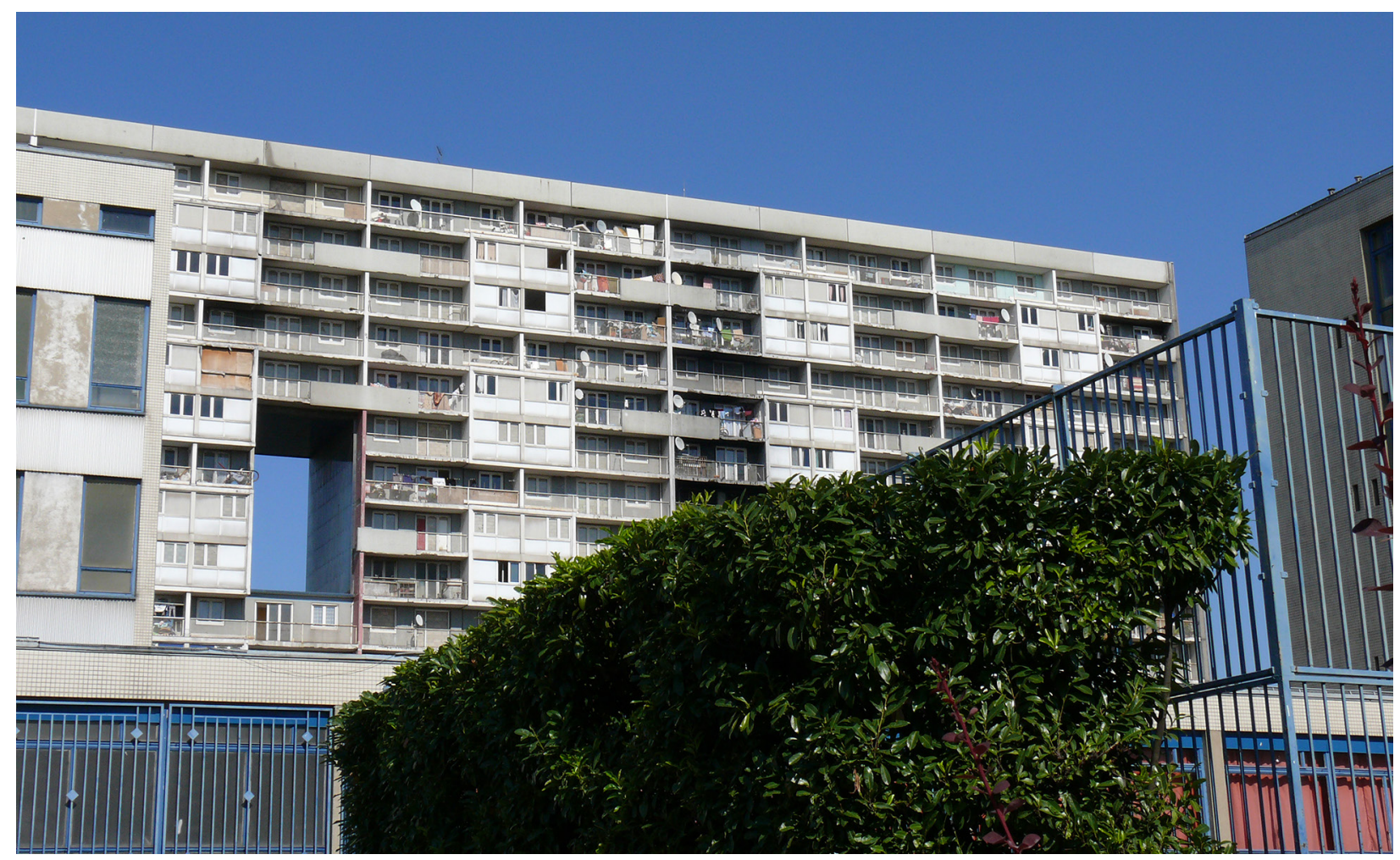

Fig. 2. 'Balzac', a high-rise block (now demolished) in the 'Cité des 4000', La Courneuve (northern rim of Paris) a synonym for poverty and drug dealing. Photo by Florian Weber (2007). 


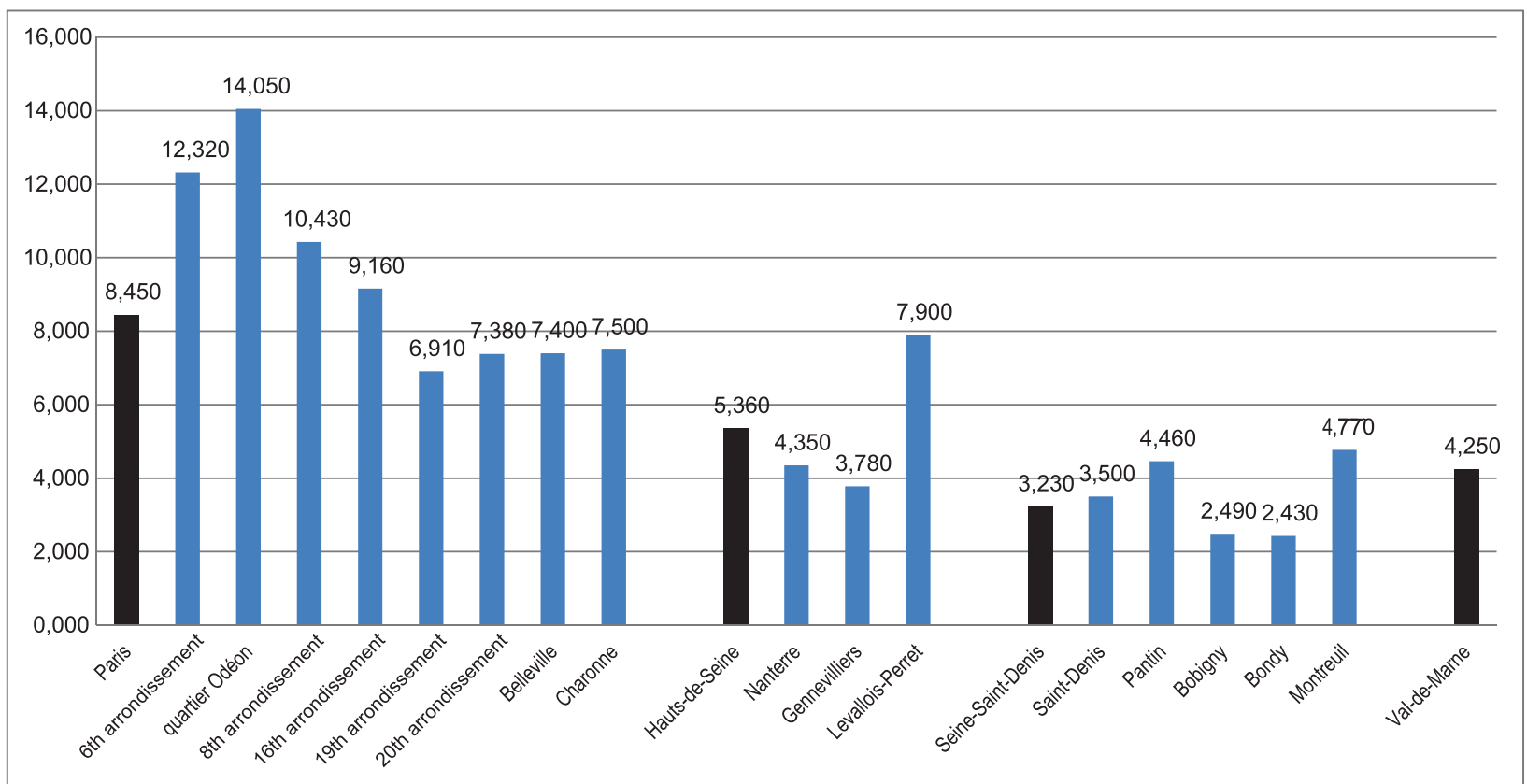

Fig. 3. Average real-estate price per sq. m. across Greater Paris (in €; first quarter 2017). Source: http:/ / www.paris.notaires.fr/outil/immobilier/carte-des-prix.

'resettlement' - of poor migrant families from the former colonies, and the simultaneous flight of households with moderate incomes (Donzelot 2004; Doytcheva 2007; Marchal, Stébé 2012; Tissot 2007; Weber 2016).

What followed was an association of banlieues with social problems which has endured to the present day (Boyer 2000: 13-20; Germes, Glasze 2010; Kirkness 2014; Kokoreff, Lapeyronnie 2013) - a stigma sealed by recurrent, widely publicised disturbances beginning in 1981 and culminating in the week-long riots that shattered France in the autumn of 2005 (Balibar 2007; Dikeç 2016; Lapeyronnie 2009; Le Goaziou, Mucchielli 2006). Dikeç (2007) speaks of banlieues in this context as the 'badlands of the republic', and many researchers focus on the issues of stigmatisation, exclusion, social intermingling, and municipal intervention (Avenel 2004; Delarue 1991; Doytcheva 2007; Glasze, Weber 2014; Kirszbaum 2015; Paquot 2008; Tissot 2007; Weber, Kühne 2016); others take a more historical and spatially diversified view of events (e.g. Boyer 2000; Paulet 2004; VieillardBaron 2011). Donzelot's $(2004,2009)$ threefold division of the French urban-rural hybrid has been widely received: gentrification of the inner-city (above all since the 1990s) - in Bourdieu's (1989) terms, the displacement of people with a lower 'symbolic capital' by those with a higher one bourgeois exclusiveness in the sprawling housing estates on the outskirts, and the downward spiral of the cités des grands ensembles, the high-rise concentrations of banlieues.

This description - convincing as far as it goes - tends, however, to ignore the variety present in banlieues, where industry and single-family housing can be found stigmatised alongside high-rise blocks, separated from them in some cases only by a highway. Nor are large housing estates uniformly problem-infested. Not all of them consist purely of public sector housing, nor are all equally devalued and stigmatised. "Contrary to the common image, these districts are not just homogeneous breeding grounds of dislocation and social handicap" (Avenel 2004: 20-21). Nor, come to that, do all low-rise housing estates radiate affluence and modernity. Banlieues should be considered rather as a complex mosaic of different elements (Weber 2016).

Another central aspect that has been largely overlooked in recent years is the process of hybridisation that has taken place in French cities as a combined result of urbanisation and gentrification (Albecker 2015; Albecker, Fol 2014; Damon et al. 2016). These become immediately evident from a comparison of the development of real-estate prices across Greater Paris (Fig. 3): in the suburbs of Levallois-Perret in the north and Montreuil in the east of the city, prices are considerably higher than in their immediate peer 
districts. Indeed, as Marchal, Stébé and Bertier have demonstrated in detail (Marchal et al. 2016; Marchal, Stébé 2012), an average price for freehold property in Levallois-Perret is almost as high as in the core city: in the first three months of 2017 it amounted to $€ 7,900$ as opposed to $€ 8,450$ per square meter respectively.

At the beginning of the 19th century the area now known as Levallois-Perret was either wholly unused or used for agriculture. In the course of industrialisation, it became an overcrowded industrial, working-class town (Faure 1991; Marchal, Stébé 2012). The wave of de-industrialisation in the 1970s saw many factories moving away, and real estate prices rose under the impact of the third and fourth industrial eras. The new Front de Seine development combines service industries with postmodern residential blocks in a single architectonic ensemble, and here, "as well as in other quarters, plate-glass towers and high-tech buildings have mushroomed out of the ground and are now housing major international firms" (Marchal et al. 2016: 101). In their wake, urbanisation and gentrification processes have taken place - driven forward at both city planning and architectonic levels - and there has been an influx of employees from the upper echelons of the service sector, with a corresponding displacement of poorer residents. These structural and infrastructural changes have given birth to a new lifestyle: "It is really very easy for the better off, the bobos [bourgeois bohèmes], to spend Saturday mornings in the popular boutiques (Bérénice, The Kooples, Sandro, IKKS, Gérard Darel) and Sundays browsing the market stalls for vegetables, health food, cheese, and wine under the watchful eye of the video cameras set up at every corner by a well equipped and armed police force" (Marchal et al. 2016: 103).

What seems contradictory to a received 'modern' perspective - indeed incompatible with it is that elements are combined and displayed in refurbished suburbs like Levallois-Perret as banners of a newfound (or rather newly constructed) identity, an aesthetic expression of self-confident postmodernity. Kühne, Schönwald and Weber have in this context coined the acronym URFSURBS: the urbanisation of former suburbs (Introduction above; Kühne 2016; Kühne et al. 2016, 2017; Kühne 2017). For a new relation has arisen "between urban restructuring, socio-demographic change and the recent growth of fragmented, hybrid and/or patchwork socio-spatial arrangements in former suburban areas" (Kühne et al. 2016: 25). Levallois-Perret exemplifies the about-turn that has occurred in such areas, where radical transformation of the architectonic substance is now far advanced and has brought with it a corresponding homogenisation of social structures (Marchal, Stébé 2012).

Another key Parisian example of the undeniably hybrid tendency toward urbanisation and

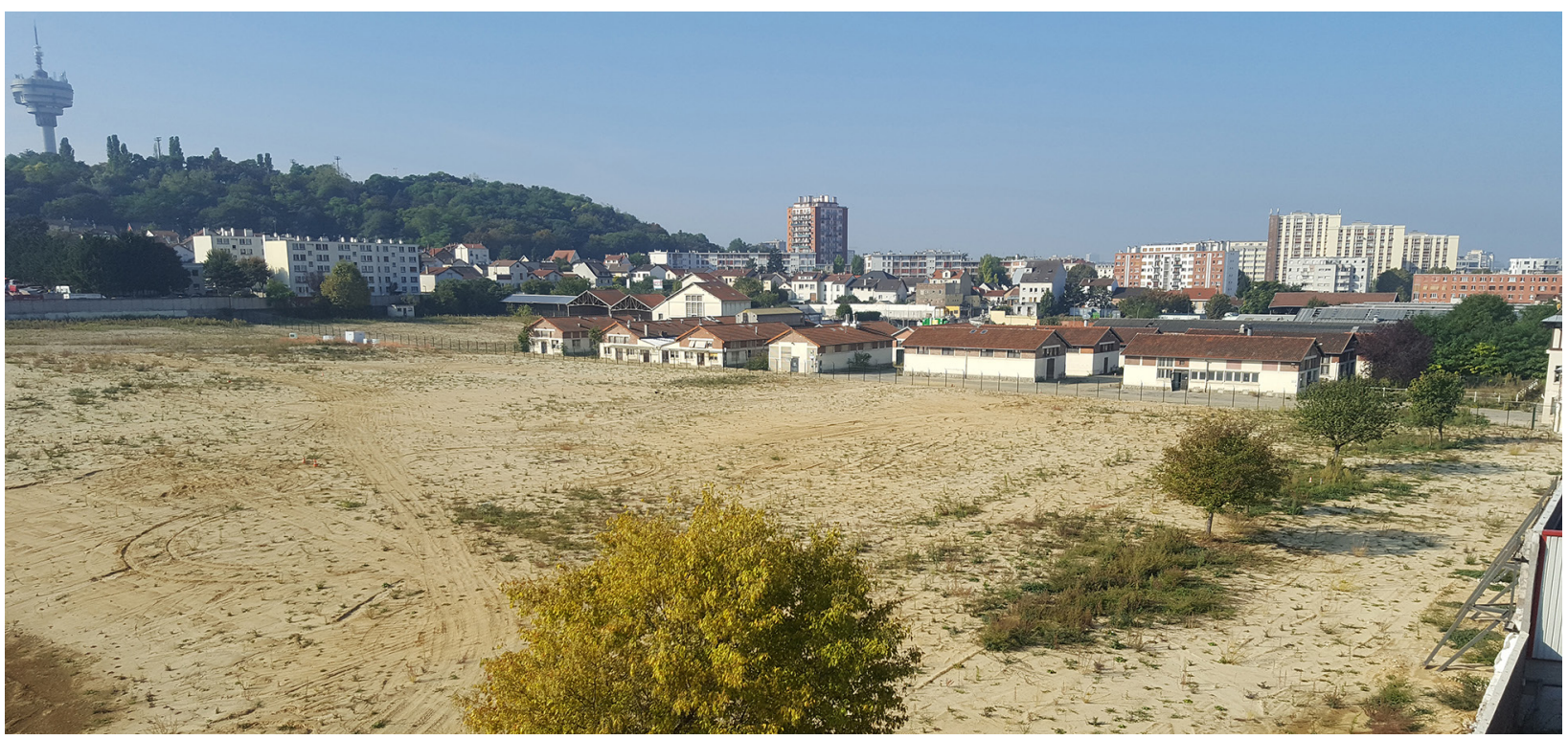

Fig. 4. Land clearance in Bobigny-Romainville, ready for high-value residential development. Photo by Florian Weber (2016). 


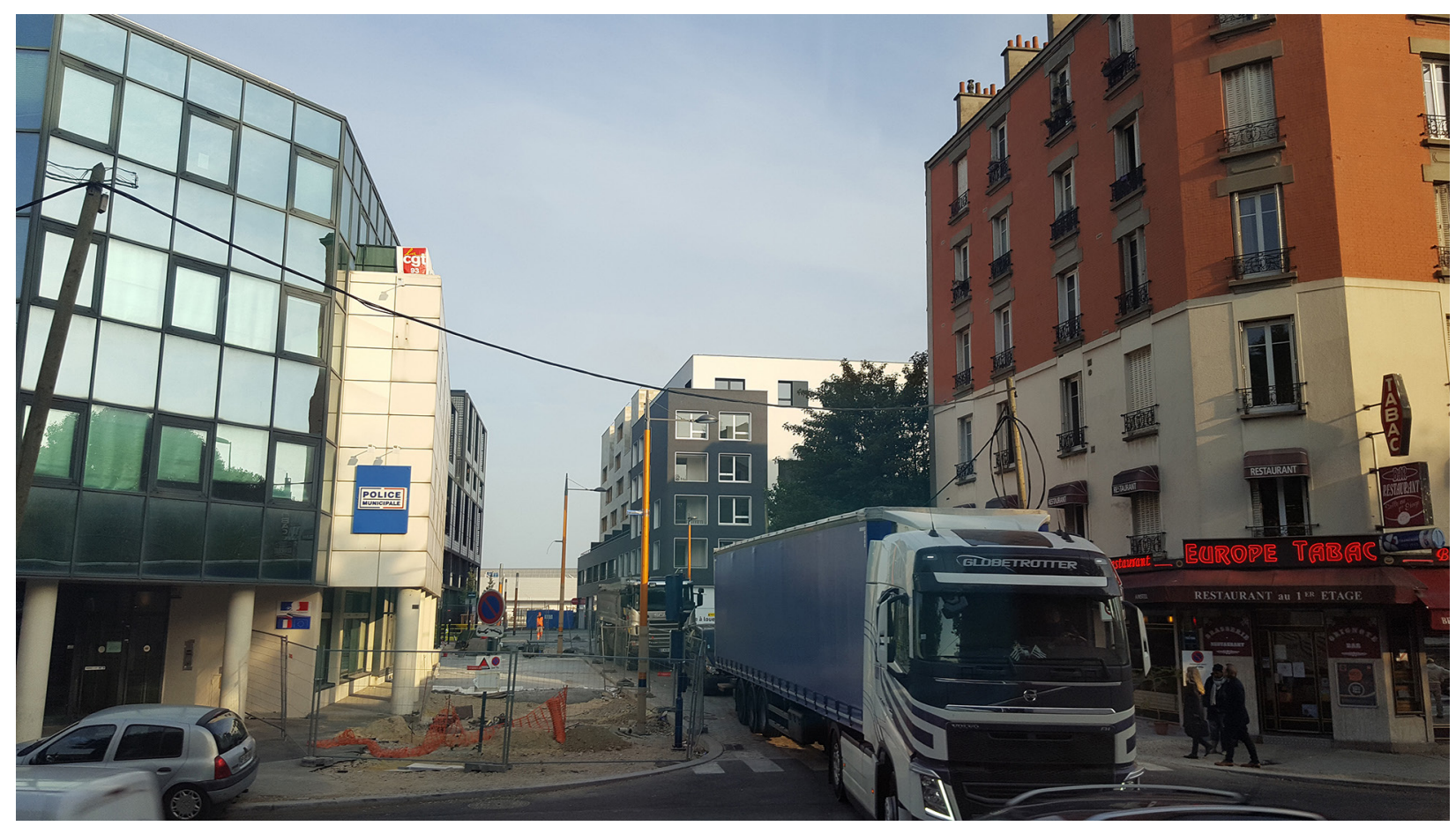

Fig. 5. Existing residential accommodation in Bobigny-Romainville with new apartment blocks in the background. Photo by Florian Weber (2016).

at least some level of gentrification is Montreuil, which again offers a rich field for current research. In Marseilles, similar tendencies can be seen in the area developed for the 2016 European Soccer championship around the stade Vélodrome, with its new shopping mall and associated architectural and social transformations.

A further object of current research is the Pantin-Bobigny-Bondy axis in eastern Greater Paris, where extensive land clearance has paved the way for high-value service-sector housing development - offered at a discount turnover-tax rate of 5.5 percent to attract better-off purchasers (Fig. 4). Already, glass-fronted offices and new apartment blocks stand cheek by jowl on busy streets with neglected, graffiti-smeared older buildings, as photographic documentation from initial field research demonstrates (Fig. 5). The shape, mood, and image of the Horloge district of Romainville (a suburb between Pantin and Bobigny) is also set to change, with an influx of new residents and businesses attracted by the construction of 850 new apartments and the provision of $270,000 \mathrm{~m}^{2}$ for economic development, above all in the health sector (Ville de Romainville 2017). Similarly, the city of Bobigny plans an injection of urban flair that will upgrade the entire area, including the construction of
1,200 apartments and 140,000 $\mathrm{m}^{2}$ of office space in the so-called Écocité along the Canal de l'Ourcq (Ville de Bobigny 2017). In contrast to LevalloisPerret, these measures - and hence, too, their hybridising and socio-structural impacts - have only just begun.

It will, then, be worth watching in the next few years to what extent these run-down buildings are replaced, and (if so) the effect it has on residential population structures. Up to now, département 93, Seine-Saint-Denis, has not exactly been a desirable address. Current plans could see some quarters of Pantin and Bobigny undergoing distinct gentrification - and with it the displacement of poorer residents to the even remoter outer circle of banlieues. To what extent these processes of what we have called URFSURBanisation have advanced (or will advance) as far as Bondy is also a matter for future investigation.

\section{Southern California. The rise or fall (?) of suburbia and the genesis of a new settlement type - the URFSURB}

In the USA a rapid spread of suburban development is a relatively recent phenomenon closely linked to mass motorisation. Individual mobility 
was the precondition for realising the dream of life in one's own home in a leafy mock-up of the countryside, insulated from the decaying blocks and rampant problems of the inner city (Hesse 2010; Kühne et al. 2016: 24). Suburbia, accordingly, became the undisputed habitat of the middle-class family (Palen 1995: 158-159), incidentally deconstructing the city as a uniquely coherent socio-spatial entity (Hall 2006; Jorgensen, Tylecote 2007; Kühne 2015). However, in its remorseless onward development, the phenomenon of sub- and ex-urbanisation has introduced still newer forms of settlement: the 'edge' and 'edgeless' cities of recent decades. Situated beyond the limits of the erstwhile suburban centres, or straggling along major traffic routes, these new settlement types represent ongoing mutations of the urban-rural hybrid (Kühne 2012, 2015; Lang et al. 2013).

Alongside its focus on the underlying processes of socio-spatial change, the current research on US suburbia also shows a certain predilection for conflict-ridden developments.
Real-estate value erosion, social segregation, and hotspots of deprivation (Hesse 2014; Hesse, Schreiner 2007; Leinberger 2008), especially in older and inner-ring suburbs, fill the pages of specialist journals. For "it is evident that many old suburbs are facing the challenge of periodical or cyclical decline, caused by selective migration, disinvestment or simply aging in the context of certain urban development trajectories. According to recent surveys, it is estimated that almost 15 per cent of the old or inner suburbs in the U.S. are subject to such changes" (Hesse 2010: section 32; Hanlon 2008, 2012; Short et al. 2007; Vicino 2008).

This is not the whole story, however. In the USA, too, "the new suburban reality is complex and looks quite different from traditional stereotypes" (Hesse 2010: section 35). A resurgent preference for city living - a short-lived 1970s movement in the same direction was soon lost to sight (Masotti, Hadden 1973) - has reurbanised suburbia, creating an entirely new settlement type: the URFSURBS described above (Kühne 2016; Kühne

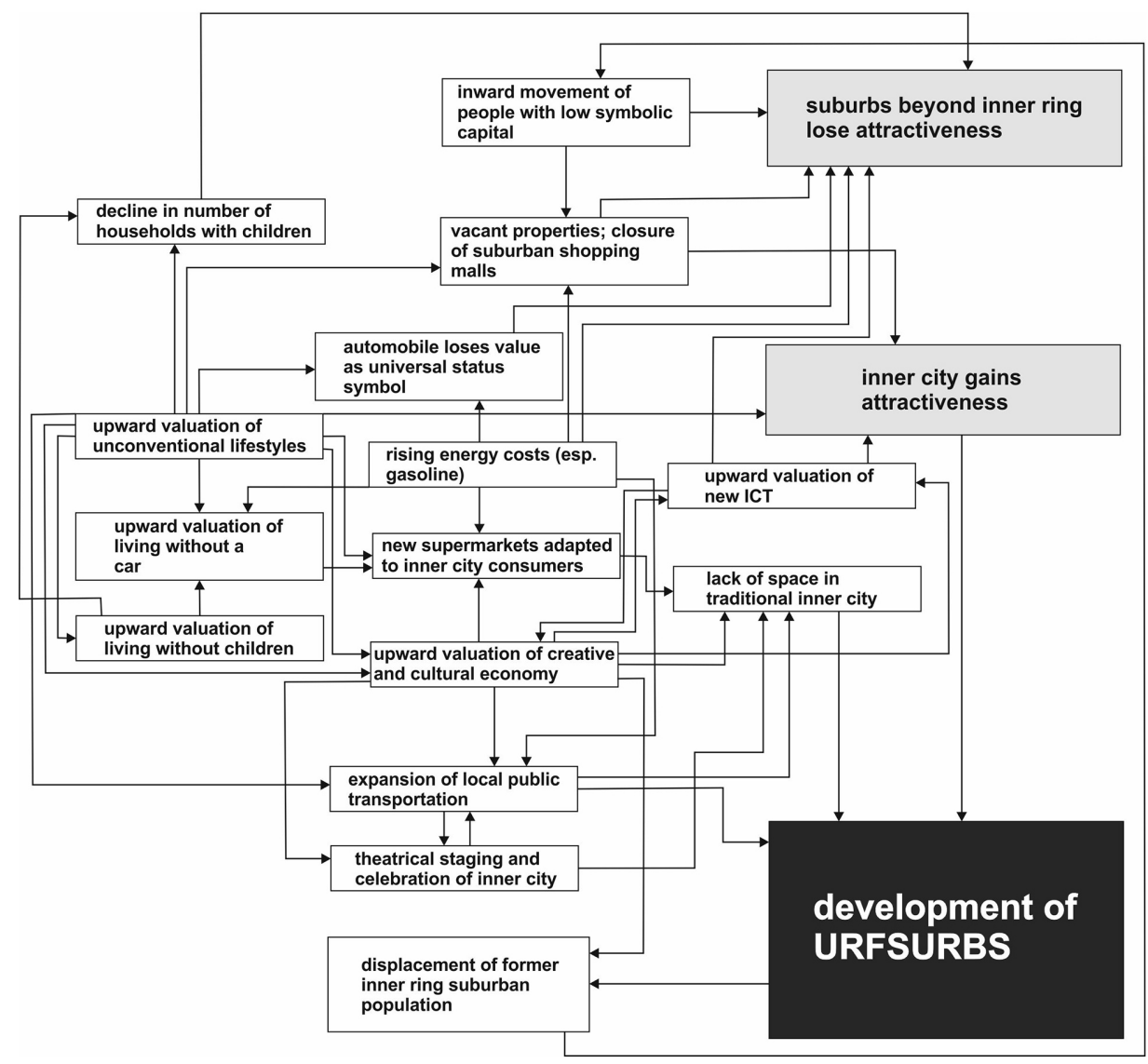

Fig. 6. URFSURBS development processes and their interrelations. Source: Kühne 2016; Kühne et al. 2017. 


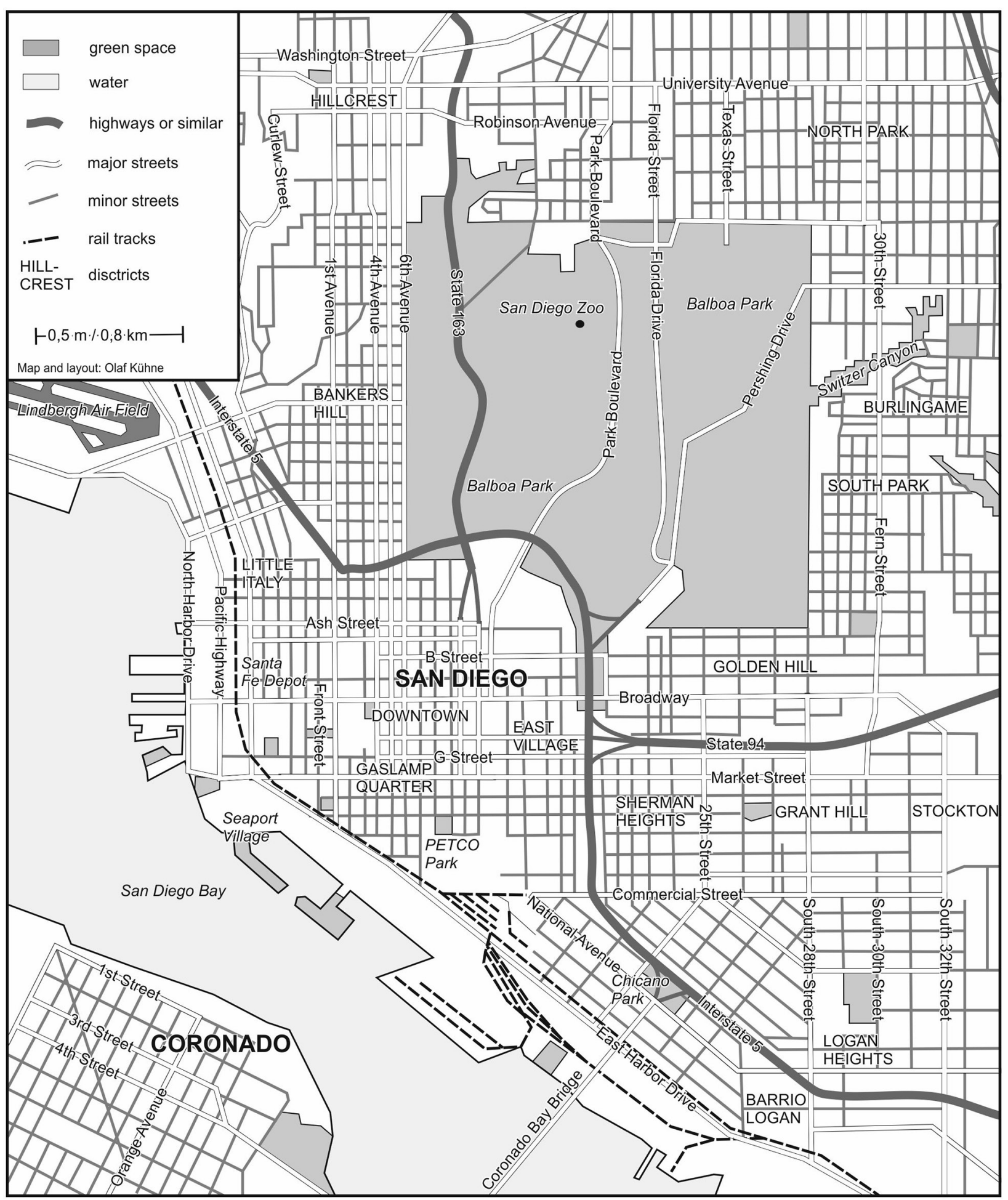

Fig. 7. Downtown and inner-circle URFSURBS in San Diego.

Source: Kühne, Schönwald 2015: 4.

et al. 2016, 2017; Kühne 2017). The phenomenon was first observed in San Diego, a centre of one of the western hemisphere's most dynamic regions: Southern California.

The URFSURBS of San Diego, like those of Los Angeles, grew out of the first generation of early 20th-century inner-ring suburbs in the wake of widespread downtown regeneration, when demand for urban living and recreational space could no longer be met without insufferable compression in the city center - understood as the modern downtown areas that formed the 
urban core of the city before the Wilson era of the mid-70s (for further detail see Kühne, Schönwald 2015). The urbanisation in question is the product of a typical inner-city economy (especially high value-added service industries), and the corresponding urban lifestyle is a specific bundle of attributes (e.g. anonymity, dress, behavioural patterns) of the people who live in that area. Postmodernisation processes have increasingly decoupled this lifestyle from downtown areas, but the phenomena of hybridisation observed in the URFSURBS of San Diego include as a defining factor the 'condensation' - albeit not always univocal in manner or extent - of such lifestyle attributes (Baker 1990; Murphy 2007 [1971]; Simmel 1950).

Downtown San Diego has in this sense expanded, assimilating former suburban space in a variety of ways: apartment blocks have been built with integrated shopping and gastronomic facilities, and the stereotypical visual expectations of the urban populace have been fulfilled in a distinctly postmodern 'architecture of experience'. The increasing importance of a creative and cultural economy has made urban locations, with their dense network of contacts, attractive; and the protagonists of this economy, with their new patterns of consumption, have promoted the start-up of alternative stores and restaurants in premises hitherto quite differently purposed, or simply disused (Gallagher 2013; Kühne, Schönwald 2015). Moreover, surging energy prices have increased the cost not only of commuting, but also of heating and air-conditioning - the latter above all in two-storey family houses (apartment blocks are more efficient in this respect) - and all these factors have made proximity to traditional downtown more desirable.

The URFSURBS of San Diego, like those of Paris, also reveal a change in the population structure, from traditional families with suburban life and consumption patterns (the latter above all in shopping malls) to an increasing number of single persons and pairs whose lifestyle and preferences are markedly urban. Accordingly, while settlements in the former inner-ring suburbs gain in attractiveness, those on the suburban periphery are losing out (Hesse 2008, 2010). Fig. 6 illustrates diagrammatically the forces at work in this process.

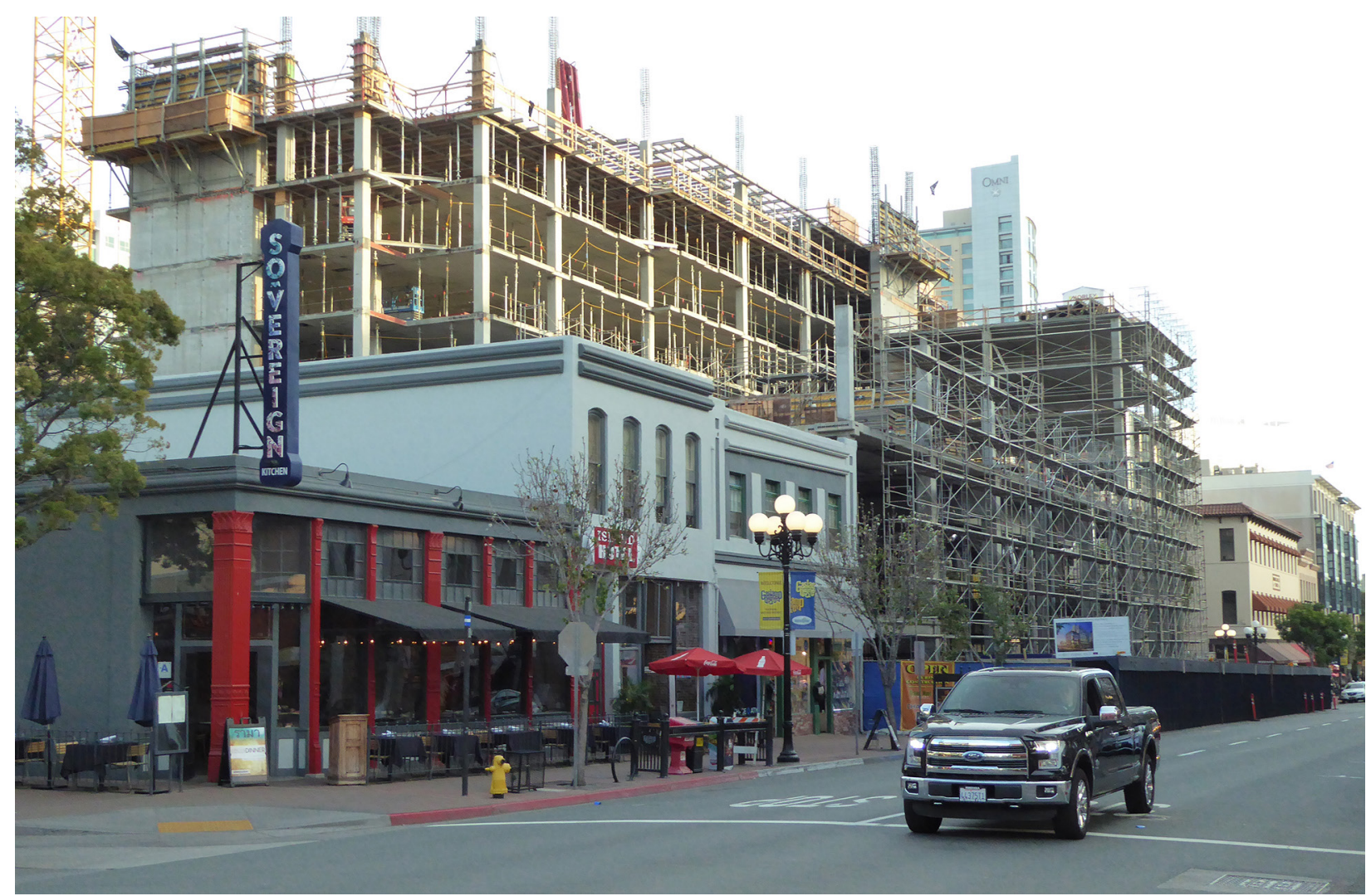

Fig. 8. Changing patterns of construction and use in Golden Hill. Photo by Olaf Kühne (2016). 
Initial attempts at systematisation based on a qualitative (and selectively quantitative) spatial analysis and (partial) systematic plotting of architectonic and social conditions (Kühne et al. 2016: 31) indicate a differentiation in the levels of URFSURBanisation, from marginal, through individualised and modified, to more or less fully restructured URFSURBS. While the physical and spatial structures of Barrio Logan, for instance, to the south of downtown San Diego, have remained largely unchanged, the district has undergone a considerable population shift, with a notable increase in the number of residents with higher cultural and social capital. In Hillcrest (north of downtown) and Golden Hill (east of downtown, Fig. 7), on the other hand, physical change is clearly visible. Single family homes have been demolished to make room for apartment blocks, and the juxtaposition of old and new - in terms of both physical property and its occupiers - is striking (Fig. 8).

\section{Concluding summary}

Given the differences between the two locations in population dynamics, planning philosophies, and spatial scales, it may seem far-fetched to compare suburbanisation processes in France and Southern California - to speak of 'edge' or 'edgeless' cities in France, for instance, would be meaningless. However, specific aspects of the processes of urbanisation, gentrification, and hybridisation - in particular their physical proximity to the urban core in both cases presented here - make such a comparison fruitful and valuable for research. In France the refurbishment of residential areas and concomitant rise in property values have until recently been associated almost exclusively with the inner city; and in the USA nobody would have thought the inner ring suburbs would undergo the sort of changes described above. After all, historically and socially, as well as economically, they were associated rather with a downward spiral. Against this background, the aim of this essay has been to follow a shift in the focus of urban geographical research toward strikingly parallel and equally unexpected movements in two different countries, and to pave the way for further research in this and allied fields.
The changing physical and architectonic patterns of space are the expression of changing social norms and values in which urban lifestyles gain in significance, while both the exorbitantly expensive inner city and the low-rise family plots of the periphery (France) or rurally tinged suburbs (USA), with all their inherited stereotypes and characteristics - e.g. socio-cultural homogeneity, classical family structures - lose out. Local political intervention, for instance in eastern Paris, suggests that the planner's ideal of social intermingling has been limited in this context by the desire to attract higher income groups to the area, and thus to reframe its image away from the negative connotations of the suburban satellite. The USA is generally less marked by interventionism of this kind, but a significant shift in the composition of the urban-rural hybrid is also evident there, in the historic heartland of suburban development. Without entirely effacing established patterns of settlement or their social basis, the spatial pastiche has thus received a new component. For although the traditional family with its spatial needs and aspirations continues to exist, its numbers - and hence its political and territorial clout - have diminished.

The development of URFSURBS differs fundamentally in this respect from the conventional extension of inner-city functions into the periphery of the CBD. It is not a further expansion into socially as well as architecturally already urbanised areas, but a complete (often also structural) transformation from suburban to urban, even though concomitant processes of gentrification and segregation may also be taking place.

As already observed, this is a phenomenon of varying intensity. Its very novelty, however, means that in all likelihood it will develop fast, and that the meagre research it has already received must be rapidly updated in both scope and detailed typology - a typology that must extend not just to physical changes but also to the underlying shifts in social dynamics and structures. Our examination of the URFSURB phenomenon has so far been confined to France and Southern California; it remains to be seen where else similar changes can be observed, what forms they take, and what their causes are. 


\section{References}

Albecker M.-F., 2015. Banlieues françaises/La banlieue parisienne, périphérie réinvestie? Online: http://www. revue-urbanites.fr/la-banlieue-parisienne-peripherie-reinvestie/* (31.08.2017).

Albecker M.-F., Fol S., 2014. The restructuring of declining suburbs in the Paris region. In: Pallagst K., Wiechmann T., Martinez-Fernandez C. (eds), Advances in geography. Vol. 8, Shrinking cities. International perspectives and policy implications. Routledge, New York, London: 78-98.

Avenel C., 2004. Sociologie des quartiers sensibles. Armand Colin, Paris.

Baker S., 1990. The sign of the self in the metropolis. Journal of Design History 3(4): 227-234.

Balibar É., 2007. Uprisings in the banlieues. Constellations. An International Journal of Critical and Democratic Theory 14(1): 47-71.

Bourdieu P., 1989. Social space and symbolic power. Sociological Theory 7(1): 14-25.

Boyer J.-C., 2000. Les banlieues en France: Territoires et sociétés. Armand Colin, Paris.

Damon J., Marchal H., Stébé J.-M., 2016. Les sociologues et le périurbain: découverte tardive, caractérisations mouvantes, controverses nourries. Revue française de sociologie 57(4): 619-939.

Dear M., Flusty S., 1998. Postmodern urbanism. Annals of the Association of American Geographers 88(1): 50-72.

Delarue J.-M., 1991. Banlieues en difficultés: La relégation: Rapport au ministre d'Etat, ministre de la ville et de l'aménagement $d u$ territoire (TEN). Syros, Paris.

Dikeç M., 2007. Badlands of the Republic: Space, politics and urban policy. Wiley-Blackwell, Malden.

Dikeç M., 2016. Rage and fire in the French banlieues. In: Mayer M., Thörn C., Thörn H. (eds), Urban uprisings. Challenging neoliberal urbanism in Europe. Palgrave Macmillan, London: 95-119.

Donzelot J., 2004. La ville à trois vitesses - relégation, périurbanisation, gentrification. In: Esprit (ed.), La ville à trois vitesses: gentrification, relégation, périurbanisation. Esprit, Paris: $14-39$.

Donzelot J., 2009. La ville à trois vitesses et autres essais. Editions de la Villette, Paris.

Doytcheva M., 2007. Une discrimination positive à la française?: Ethnicité et territoire dans les politiques de la ville. La Découverte, Paris.

Ellin N., 1999. Postmodern urbanism. Princeton Architectural Press, New York.

Faure A. (ed.), 1991. Les premiers banlieusards: Aux origines des banlieues de Paris (1860-1940). Editions Créaphis, Paris.

Gallagher L., 2013. The end of the auburbs: Where the American dream is moving. Portfolio/Penguin, New York.

Germes M., Glasze G., 2010. Die banlieues als Gegenorte der République: Eine Diskursanalyse neuer Sicherheitspolitiken in den Vorstädten Frankreichs. Geographica Helvetica 65(3): 217-228.

Glasze G., Weber F., 2014. Die Stigmatisierung der banlieues in Frankreich seit den 1980er Jahren als Verräumlichung und Ethnisierung gesellschaftlicher Krisen. Europa Regional 20 (2012) (2-3): 63-75.

Hall T., 2006. Urban geography. Routledge, London, New York.

Hanlon B., 2008. The decline of older, inner suburbs in metropolitan America. Housing Policy Debate 19(3): 423-456.
Hanlon B., 2012. Once the American dream: Inner-ring suburbs of the metropolitan United States. Temple University Press, Philadelphia.

Hesse M., 2008. Resilient suburbs? Ungleiche Entwicklungsdynamiken suburbaner Räume in Nordamerika im Zeichen der Kreditkrise. Geographische Zeitschrift 96(4): 228-249.

Hesse M., 2010. Suburbs: The next slum?: Explorations into the contested terrain of social construction and political discourse. Journal of Urban Research (special issue 3): 43 Absätze.

Hesse M., 2014. Just „dump and boring“, or over? Lifecycle-trajectories, the credit-crunch and the challenge of suburban regeneration in the US. In: O'Donoghue D.P. (ed.), Urban transformations. Centres, peripheries and systems. Ashgate, Farnham: 151-159.

Hesse M., Schreiner J., 2007. Suburban areas - Problem neighbourhoods of the future? Online: http://www. difu.de/5941* (30.01.2017).

Hoesterey I., 2001. Pastiche: Cultural memory in art, film, literature. Indiana University Press, Bloomington.

Jorgensen A., Tylecote M., 2007. Ambivalent landscapes Wilderness in the urban interstices. Landscape Research 32(4): 443-462.

Kirkness P., 2014. The cités strike back: Restive responses to territorial taint in the French banlieues. Environment and Planning A 46(6): 1281-1296.

Kirszbaum T. (ed.), 2015. En finir avec les banlieues?: Le désenchantement de la politique de la ville. Editions de l'Aube, La Tour d'Aigues.

Kling R., Olin S.C., Poster M., 1995. The emergence of post suburbia: An introduction. In: Kling R., Olin S.C., Poster M. (eds), Postsuburban California. The transformation of Orange County since World War II. University of California Press, Berkeley: 1-30.

Kokoreff M., Lapeyronnie D., 2013. Refaire la cité: L'avenir des banlieues. La République des idées. Seuil, Paris.

Kühne O., 2012. Stadt - Landschaft - Hybridität: Ästhetische Bezüge im postmodernen Los Angeles mit seinen modernen Persistenzen. Springer VS, Wiesbaden.

Kühne O., 2015. The streets of Los Angeles: Power and the infrastructure landscape. Landscape Research 40(2): 139-153.

Kühne O., 2016. Transformation, Hybridisierung, Streben nach Eindeutigkeit und Urbanizing former Suburbs (URFSURBS): Entwicklungen postmoderner Stadtlandhybride in Südkalifornien und in Altindustrieräumen Mitteleuropas - Beobachtungen aus der Perspektive sozialkonstruktivistischer Landschaftsforschung. In: Hofmeister S., Kühne O. (eds), StadtLandschaften. Die neue Hybridität von Stadt und Land. Springer VS, Wiesbaden: 13-36.

Kühne O., 2017. Hybridisierungstendenzen, Raumpastiches und URFSURBs in Südkalifornien als Herausforderung für die Planung. In: Berr K. (ed.), Architektur- und Planungsethik. Zugänge, Perspektiven, Standpunkte. Springer VS, Wiesbaden: 15-32.

Kühne O., Schönwald A., 2015. San Diego: Eigenlogiken, Widersprüche und Hybriditäten in und von, America's finest city'. Springer VS, Wiesbaden.

Kühne O., Schönwald A., Weber F., 2016. Urban / rural hybrids: The urbanisation of former suburbs (URFSURBS). Quaestiones Geographicae 35(4): 23-34.

Kühne O., Schönwald A., Weber F., 2017. Die Ästhetik von Stadtlandhybriden: URFSURBS (Urbanizing former suburbs) in Südkalifornien und im Großraum Paris. In: Küh- 
ne O., Megerle H., Weber F. (eds), Landschaftsästhetik und Landschaftswandel. Springer VS, Wiesbaden: 177-198.

Lang R.E., Sanchez T.W., Oner A.C., 2013. Beyond edge city: Office geography in the new metropolis. Urban Geography 30(7): 726-755.

Lapeyronnie D., 2009. Primitive rebellion in the French banlieues: On the Fall 2005 riots. In: Tshimanga C., Gondola D., Bloom P.J. (eds), Frenchness and the African diaspora. Identity and uprising in contemporary France. Indiana University Press, Bloomington: 21-46.

Le Goaziou V., Mucchielli L. (eds), 2006. Quand les banlieues brûlent ... Retour sur les émeutes de novembre 2005. La Découverte, Paris.

Leinberger C.B., 2008. The next slum? The Atlantic Monthly 3: $70-75$.

Marchal H., Stébé J.-M., 2012. Les lieux des banlieues: De Paris à Nancy, de Mumbaï à Los Angeles. Le Cavalier bleu, Paris.

Marchal H., Stébé J.-M., Bertier M., 2016. Die französische banlieue mit den zwei Gesichtern des Januskopfes. In: Weber F., Kühne O. (eds), Fraktale Metropolen. Stadtentwicklung zwischen Devianz, Polarisierung und Hybridisierung. Springer VS, Wiesbaden: 93-116.

Masotti L.H., Hadden J.K. (eds), 1973. The urbanization of the suburbs. SAGE Publications, Beverly Hills.

McManus R., Ethington P.J., 2007. Suburbs in transition: new approaches to suburban history. Urban History 34(2): 317-337.

Murphy R.E., 2007 [1971]. The central business district: A study in urban geography. Routledge, London.

Palen J.J., 1995. The suburbs. McGraw-Hill, New York.

Paquot T. (ed.), 2008. Espace en société. Penseurs d'espace. Banlieues: Une anthologie. Presses polytechniques et universitaires romandes, Lausanne.

Paulet J.-P., 2004. Les banlieues françaises. Ellipses, Paris.

Short J.R., Hanlon B., Vicino T.J., 2007. The decline of inner suburbs: The new suburban Gothic in the United States. Geography Compass 1(3): 641-656.

Simmel G., 1950. The metropolis and mental life. In: Wolff K.H. (ed.), The sociology of Georg Simmel. The Free Press, Glencoe, Illinois: 409-424.

Soulignac F., 1993. La banlieue parisienne - cent cinquante ans de transformations. La documentation française, Paris.

Stébé J.-M., Marchal H., 2007. La sociologie urbaine (5. Auflage). Que sais-je? Vol. 3790. Puf, Paris.
Teaford J.C., 2011. Suburbia and post-suburbia: A brief history. In: Phelps N.A., Wu F. (eds), International perspectives on suburbanization. A post-suburban world? Palgrave Macmillan, London: 15-34.

Thinard F., 2008. Les banlieues. Les clés de l'info. La documentation française, Paris.

Tissot S., 2007. L'Etat et les quartiers: Genèse d'une catégorie de l'action publique. Seuil, Paris.

Vester H.-G., 1993. Soziologie der Postmoderne. Quintessenz, München.

Vicino T.J., 2008. The quest to confront suburban decline: Political realities and lessons. Urban Affairs Review 43(4): 553-581.

Vieillard-Baron H., 1996. Les banlieues. Un exposé pour comprendre. Un essai pour réfléchir. Flammarion, Paris.

Vieillard-Baron H., 2008. La banlieue : question de définition. In: Paquot T. (ed.), Espace en société. Penseurs d'espace, banlieues. Une anthologie. Presses polytechniques et universitaires romandes, Lausanne: 21-34.

Vieillard-Baron H., 2011. Banlieues et péripheries: Des singularités françaises aux réalités mondiales (2. éd. revue et augmentée). Carré géographie, Vol. 6. Hachette, Paris.

Ville de Bobigny, 2017. Sur les bords du canal de l'Ourcq : l'Écocité. Online: http://www.bobigny.fr/646/sur-lesbords-du-canal-de-lourcq-lecocite.htm* (31.08.2017).

Ville de Romainville, 2017. Un quartier qui change. Online: http://horloge-romainville.fr/* (31.08.2017).

Weber F., 2016. Urbane Mosaike, Fragmentierungen, stadtpolitische Interventionen. Die banlieues und die Stadtpolitik politique de la ville. In: Weber F., Kühne O. (eds), Fraktale Metropolen. Stadtentwicklung zwischen Devianz, Polarisierung und Hybridisierung. Springer VS, Wiesbaden: 21-55.

Weber F., 2017. Landschaftsreflexionen am Golf von Neapel. Déformation professionnelle, Meer-Stadtlandhybride und Atmosphäre. In: Kühne O., Megerle H., Weber F. (eds), Landschaftsästhetik und Landschaftswandel. Springer VS, Wiesbaden: 199-214.

Weber F., Glasze G., Vieillard-Baron H., 2012. Krise der banlieues und die politique de la ville in Frankreich. Geographische Rundschau 64(6): 50-56.

Weber F., Kühne O. (eds), 2016. Fraktale Metropolen: Stadtentwicklung zwischen Devianz, Polarisierung und Hybridisierung. Springer VS, Wiesbaden. 